\title{
Peningkatan Kemampuan Berpikir Kritis Matematis dan Kemandirian Belajar Siswa melalui Model Pembelajaran Problem Solving
}

\author{
Renilda Ririn ${ }^{1 *}$, Hedi Budiman ${ }^{2}$, Guntur Maulana Muhammad ${ }^{3}$ \\ ${ }^{1,2,3}$ Universitas Suryakancana \\ *ririnrenilda19@gmail.com
}

\begin{abstract}
Abstrak
Penelitian ini bertujuan untuk mengetahui apakah model pembelajaran problem solving dapat meningkatkan kemampuan berpikir kritis matematis dan kemandirian belajar siswa. Metode penelitian menggunakan eksperimen kuasi. Untuk kelas eksperimen diberikan perlakuan dengan menggunakan model pembelajaran problem solving, sedangkan kelas kontrol diberikan pembelajaran yang biasa dilakukan guru saat mengajar (discovery learning). Populasi yang diambil dalam penelitian ini yaitu siswa kelas VIII SMP di Ciranjang tahun pelajaran 2019/2020. Sedangkan sampel yang digunakan sebanyak dua kelas yaitu kelas VIIIA sebagai kelas eksperimen dan kelas VIIIB sebagai kelas kontrol. Hasil penelitian menunjukkan bahwa peningkatan kemampuan berpikir kritis matematis dengan menggunakan model pembelajaran problem solving tidak lebih baik atau sama dengan menggunakan model discovery learning dan hasil angket serta lembar observasi kemandirian belajar menunjukkan bahwa kemandirian belajar siswa dengan model pembelajaran problem solving lebih baik dibandingkan dengan model discovery learning.
\end{abstract}

Kata Kunci: Berpikir kritis matematis, Kemandirian belajar siswa, Model pembelajaran problem solving.

\begin{abstract}
The study aims to determine whether the problem solving learning model can enhance mathematical critical thinking skills and student self regulated learning. The research method used a quasi experimental. The experimental class used problem solving learning model, while the control class used discovery learning. The population was students of SMP $8^{\text {th }}$ at Ciranjang in the academic year 2019/2020. The sample used two class as an experimental and a control class. The results showed that there was no difference the enhancement of mathematical critical thinking skills using problem solving learning model and discovery learning model. For self regulated learning, the result of questionnaire and observation showed that problem solving learning model class better than discovery learning model class.
\end{abstract}

Keywords: Mathematical critical thinking, Student Self regulated Learning, Problem solving learning model

\section{Pendahuluan}

Perkembangan ilmu pengetahuan dan teknologi mengharuskan setiap individu untuk menyesuaikan diri dengan perkembangan zamannya. Perkembangan zaman ini berdampak juga bagi dunia pendidikan. Pendidikan saat ini harus benar-benar menciptakan lulusan yang berkualitas. Oleh karena itu, yang harus diperhatikan guru adalah hasil belajar siswa. Selain hasil belajar yang baik, siswa juga harus memiliki berbagai kemampuan. Salah satunya adalah kemampuan berpikir kritis. Terutama dalam pembelajaran matematika yang lebih mengandalkan kemampuan daya pikir. Johnson \& Siegel, 2010: 
104 (Puspaningtyas, 2019) berpendapat bahwa berpikir berhubungan dengan perkembangan kemampuan untuk memahami, menganalisis, mengkritik, dan membangun pendapat. Dengan kemampuan berpikir kritis siswa diharapkan dapat mengatasi dan menyelesaikan permasalahan matematika yang materinya cenderung abstrak.

Kemampuan berpikir kritis merupakan kemampuan berpikir tingkat tinggi. Ennis (1962) mengungkapkan bahwa berpikir kritis adalah berpikir secara beralasan dan reflektif dengan menekankan pada pembuatan keputusan tentang apa yang harus dipercayai atau dilakukan. Dengan demikian, kemampuan berpikir kritis sangat penting dimiliki oleh siswa, karena dalam kehidupan sehari-hari cara seseorang mengarahkan hidupnya bergantung pada pernyataan yang dipercayainya, dan pernyataan yang diterima.

Dengan menumbuhkembangkan kemampuan berpikir kritis siswa, diharapkan agar siswa siap menyesuaikan diri dengan kehidupannya dan mampu menghadapi berbagai permasalahan personal maupun sosial dalam kehidupannya. Namun kenyataannya yang terjadi, kemampuan berpikir kritis matematis siswa masih sangat rendah dan perlu dikembangkan (Herdiman, dkk. 2018). Hal ini disebabkan oleh beberapa faktor, salah satunya adalah proses pembelajaran yang dilaksanakan. Selama ini proses pembelajaran di kelas masih didominasi oleh guru sehingga belum memberikan keleluasan kepada siswa untuk lebih mandiri dalam menyelesaikan permasalahan yang diberikan melalui penemuan dan proses berpikir. Siswa selalu menghafal tanpa tahu konsep dari materi yang telah dipelajari, karena siswa tidak pernah dilatih untuk berpikir kritis. Setiawan (Widayanti \& Nur'aini, 2020) mengemukakan bahwa "Pembelajaran matematika hendaknya dimulai dengan pengenalan masalah atau mengajukan masalah riil atau nyata, yaitu pembelajaran yang mengaitkan dengan kehidupan sehari-hari siswa, kemudian siswa secara bertahap dibimbing untuk menguasai konsep matematika dengan melibatkan peran aktif siswa dalam proses pembelajaran".

Berdasarkan hasil penelitian Herdiman, dkk (2018) mengungkapkan bahwa kemampuan berpikir kritis matematis siswa masih sangat rendah. Siswa belum bisa memberikan alasan atau kesimpulan yang logis dalam menyelesaikan masalah. Kurangnya pemahaman siswa disaat menentukan rumus awal dan menentukan penyelesaian secara sistematis dalam menyelesaikan masalah.

Di lihat dari kenyataan tersebut, jelas bahwa kemampuan berpikir kritis dalam matematika perlu dilatih dan dibiasakan kepada siswa sedini mungkin. Sehingga pada saat siswa diperhadapkan dengan masalah matematika dengan situasi matematika yang baru 
ditemuinya, maka siswa dapat menemukan ide dan beragumen, serta mengambil kesimpulan yang logis yang dapat dipercayai untuk menyelesaikan masalah dengan situasi tersebut.

Kemandirian belajar sangat penting dimiliki oleh siswa agar mampu meningkatkan prestasi belajarnya. Hal ini sejalan dengan pendapat Suid, dkk (2017) mengungkapkan bahwa kemandirian belajar merupakan salah satu faktor yang menentukan keberhasilan siswa dalam belajar, sehingga sikap mandiri ini penting dimiliki oleh siapa saja yang ingin mencapai kesuksesan dalam hidupnya. Menurut Listyani (Saefullah, Siahaan, \& Sari, 2013) ada enam indikator yang dapat digunakan untuk mengukur kemandirian belajar siswa yaitu: 1) tidak tergantung terhadap orang lain, 2) Memiliki kepercayaan diri, 3) berpelilaku disiplin, 4) memiliki rasa tanggung jawab, 5) berperilaku berdasarkan inisiatif sendiri, dan 6) melakukan kontrol diri.

Individu yang mandiri adalah individu yang mampu mewujudkan kehendak atau realisasi diri tanpa bergantung dengan orang lain. Elfira (2013) menyatakan bahwa untuk menjadi individu yang mandiri tentu tidak mudah, apalagi mandiri dalam belajar. Ada beberapa faktor yang dapat mempengaruhi individu untuk menjadi mandiri dalam belajar, diantaranya faktor internal dan faktor eksternal.

Menurut Muntholi'ah (Arora, Erlamsyah, \& Syahniar, 2013) faktor dari luar (faktor eksternal) yang dapat mempengaruhi kemandirian anak adalah kebudayaan dan pola pengasuhan orangtua terhadap anak. Kemandirian anak berawal dari keluarga serta dipengaruhi oleh perlakuan dari orangtua. Di dalam keluarga, orangtua berperan dalam mengasuh, membimbing, dan membantu, mengarahkan anak untuk menjadi mandiri. Faktor eksternal lain yang dapat mempengaruhi kemandirian belajar siswa adalah pembelajaran di sekolah. Pembelajaran yang menuntut siswa untuk mencari dan mengolah informasi dalam menyelesaikan permasalahan yang diberikan saat belajar di kelas dapat menumbuhkan sikap mandiri siswa untuk belajar. Huda, dkk (2019) mengungkapkan bahwa pembelajaran berbasis masalah menuntut kemandirian peserta didik dalam memecahkan masalah kehidupan sehari-hari dan menjadi modal bagi peserta didik untuk menghadapi tantangan masa depan. Sedangkan faktor internal yang dapat mempengaruhi kemandirian belajar siswa merupakan dorongan atau pengaruh yang timbul dari dalam diri siswa sendiri. Misalnya inisiatif belajar, kepercayaan diri, bertanggung jawab, dan disiplin.

Meskipun kemandirian belajar penting, pada kenyataannya saat ini kebanyakan siswa belum mampu secara mandiri untuk menemukan, mengenal, serta merinci hal-hal 
yang timbul dari permasalahan yang diberikan. Hal ini dikarenakan siswa awalnya hanya menuruti apa saja yang disajikan oleh guru atau masih bergantung pada guru. Jika siswa diharapkan menjadi siswa yang mandiri, maka guru harus bisa membuat siswa aktif sendiri dalam menemukan hal-hal baru yang dapat membuat siswa menyelesaikan permasalahan yang diberikan dalam kegiatan pembelajaran.

Berdasarkan hasil penelitian Handayani \& Hidayat (2018) mengungkapkan bahwa terdapat hubungan positif dan signifikan kemandirian belajar terhadap hasil belajar matematika. Hubungan antara kemandirian belajar dengan hasil belajar matematika adalah semakin tinggi tingkat kemandirian belajar maka akan semakin tinggi hasil belajar matematika siswa begitu juga sebaliknya semakin rendah tingkat kemandirian belajar makan akan semakin rendah juga hasil belajar matematika siswa.

Untuk dapat mengatasi permasalahan tentang rendahnya kemampuan berpikir kritis matematis siswa dan rendahnya kemandirian belajar siswa, maka perlu diterapkan suatu model pembelajaran yang dapat meningkatkan kemampuan berpikir kritis matematis siswa dan kemandirian belajar siswa. Salah satu model pembelajaran yang sesuai dengan permasalahan di atas adalah model pembelajaran Problem Solving. Karena dengan model pembelajaran problem solving siswa bisa lebih aktif dalam memecahkan masalah yang diberikan dalam kegiatan pembelajaran. Menurut Hidayat \& Ihsan (2020) pembelajaran berbasis masalah menuntut siswa untuk dapat memecahkan masalah yang diberikan dengan cara mereka sendiri sehingga memunculkan kemampuan berfikir kreatif matematis.

Problem solving merupakan suatu model pembelajaran yang berpusat pada keterampilan pemecahan masalah, yang diikuti dengan penguatan kreatifitas. Menurut As'ari (Aris Shoimin, 2014:135) model pembelajaran problem solving merupakan suatu pembelajaran yang memusatkan pada pengajaran dan keterampilan untuk bisa mencari atau menemukan solusi atau cara penyelesaian masalah. Model pembelajaran problem solving adalah model pembelajaran yang memberi peluang siswa untuk memecahkan masalah yang diberikan secara mandiri sehingga mampu memperoleh konsep dan kemudian mampu menerapkan konsep yang telah diperolehnya untuk memecahkan masalah dalam bentuk lainnya, Djamarah \& Zain (Firmansyah, Wonorahardjo, \& Arief. 2016). Menurut Dewi \& Septa (2019) proses pembelajaran matematika pada dasarnya bukan sekedar transfer gagasan namun proses mengkonstruksi pengetahuan siswa. Dengan pembelajaran berbasis masalah siswa memulai pembelajaran dengan masalah yang diberikan sehingga siswa 
berfikir dan memiliki gagasan untuk menyelesaikan masalah yang kemudian mengkonstruksinya sebagai pengetahuan baru.

Selain model pembelajaran problem solving, model discovery learning juga dapat membantu siswa dalam meningkatkan kemampuan berpikir kritisnya dan kemandirian belajarnya. Menurut Nugrahaeni, dkk (2017) model discovery learning merupakan suatu rangkaian kegiatan belajar yang melibatkan secara maksimal seluruh kemampuan siswa untuk mencari dan menyelidiki secara sistematis, kritis, logis, analitis sehingga mereka dapat merumuskan sendiri penemuannya. Jerome S. Bruner (Nurrohmi, dkk. 2017) berpendapat bahwa pada model discovery learning terdapat enam sintaks, yaitu stimulasi, identifikasi masalah, pengumpulan data, pengolahan data, verifikasi dan generalisasi akan mampu menjadikan pemikiran kritis pada siswa menjadi terarah.

Model discovery learning berpengaruh terhadap kemampuan berpikir kritis siswa. Hal ini sesuai dengan hasil penelitian yang dilakukan Nurlaeli (2015) menyatakan bahwa setelah dilatihkan keterampilan berpikir kritis pada siswa selama proses pembelajaran dengan menggunakan discovery learning berorientasi saintifik pada topic perubahan materi; $70 \%$ siswa memiliki keterampilan berpikir kritis tinggi; $10 \%$ siswa memiliki keterampilan berpikir cukup kritis; dan $20 \%$ siswa memiliki keterampilan berpikir kurang kritis (Nurrohmi, dkk. 2017).

Selain model pembelajaran problem solving \& model discovery learning, menurut Herlina \& Ihsan (2020) pengembangan LKPD perlu dilakukan di sekolah karena LKPD dengan model PBL dapat melatih siswa untuk belajar berpikir kritis dalam memecahkan masalah matematika.

Analisis diatas mendorong dilakukannya penelitian untuk menjawab permasalahan Apakah peningkatan kemampuan berpikir kritis matematis siswa yang menggunakan model pembelajaran Problem Solving lebih baik daripada yang menggunakan model Discovery Learning. Dan apakah kemandirian belajar siswa yang menggunakan model pembelajaran Problem Solving lebih baik daripada yang menggunakan model Discovery Learning.

\section{Metode Penelitian}

Metode penelitian yang digunakan dalam penelitian ini adalah metode eksperimen kuasi, dengan desain Nonequivalent Control Grup Design. Pada desain ini kelompok eksperimen maupun kelompok kontrol tidak dipilih secara random. Hal ini sesuai dengan 
desain penelitian nonequivalent control grup design yang memilih sampel tidak secara random melainkan dengan tujuan tertentu yaitu melihat kesetaraan antara kelas kontrok dan kelas eksperimen. Populasi penelitian ini adalah siswa kelas VIII SMP PUSAKA Ciranjang sedangkan sampel yang diambil dalam penelitian ini adalah kelas VIII-A berjumlah 19 orang dan kelas VIII-B berjumlah 19 orang yang dipilih secara Purposive sampling. Penentuan sampel dilakukan untuk menentukan satu kelas eksperimen dan satu kelas kontrol. Kelas eksperimen akan menerima pembelajaran dengan menggunakan model pembelajaran problem solving, dan kelas kontrol akan menerima pembelajaran dengan model discovery learning. Dalam penelitian ini kelas VIII-A digunakan sebagai kelas eksperimen dan kelas VIII-B digunakan sebagai kelas kontrol. Dalam penelitian ini variabel bebas adalah model pembelajaran problem solving, sedangkan variabel terikat adalah kemampuan berpikir kritis dan kemandirian belajar siswa.

Instrumen pembelajaran yang digunakan dalam penelitian ini yaitu Silabus, Rencana Pelaksanaan Pembelajaran (RPP), dan Lembar Kerja Siswa (LKS). Sedangkan instrumen yang digunakan untuk melihat proses dan hasil belajar mengajar yaitu instrumen tes yang diberikan pada awal dan akhir penelitian untuk mengukur peningkatan kemampuan berpikir kritis matematis, dan instrumen non tes yang dilihat dari angket yang diberikan sebanyak 2 kali yaitu pada awal dan akhir penelitian dan lembar observasi yang dilakukan 3 kali atau setiap pertemuan untuk mengukur peningkatan kemandirian belajar siswa.

\section{Hasil dan Pembahasan}

Rekapitulasi hasil penelitian kemampuan berpikir kritis matematis siswa antara yang menggunakan model pembelajaran problem solving dengan model discovery learning disajikan dalam tabel berikut:

Tabel 1. Statistik Deskriptif Hasil Tes Kemampuan Berpikir Kritis Matematis

\begin{tabular}{|c|c|c|c|c|c|c|c|}
\hline \multicolumn{2}{|c|}{ Kemampuan } & \multicolumn{3}{|c|}{ Kelas Eksperimen } & \multicolumn{3}{c|}{ Kelas Kontrol } \\
\cline { 2 - 8 } \multicolumn{2}{|c|}{} & Pretest & Posttest & Gain & Pretest & Posttest & Gain \\
\hline \multirow{2}{*}{$\begin{array}{c}\text { Berpikir } \\
\text { Kritis }\end{array}$} & $\bar{x}$ & 3,58 & 11,16 & 46,2015 & 2,89 & 10,00 & 41,6965 \\
\cline { 2 - 8 } & S & 1,774 & 3,625 & 22,41208 & 2,979 & 3,902 & 18,82942 \\
\hline
\end{tabular}

Keterangan: Skor Maksimum Ideal (SMI) tes kemampuan berpikir kritis matematis $=20$

Pada tabel 1 rerata gain kelas eksperimen dan gain kelas kontrol yaitu 46,2015 dan 41,6965 dengan simpangan baku masing-masing 22,41208 dan 18,82942. Artinya secara 
deskriptif peningkatan kemampuan berpikir kritis matematis kelas eksperimen lebih baik daripada kelas kontrol. Gain dilakukan untuk mengetahui peningkatan kemampuan berpikir kritis matematis siswa. Gain diperoleh dari nilai pretest dan posttest. Gain dihutung dengan rumus dari Meltzer (Ifanda, 2019):

$$
\text { Indeks gain }=\frac{\text { skor posttest }- \text { skor pretest }}{\text { skor maksimal ideal }- \text { skor pretest }}
$$

Selanjutnya akan diuji kemampuan berpikir kritis yang lebih baik antara kelas eksperimen dan kelas kontrol terlebih dahulu menguji pretest untuk memastikan bahwa kedua kelas tersebut memiliki kemampuan awal yang sama. Berikut hasil pengujiannya:

Tabel 2. Uji Mann Whitney Data Pretest

\begin{tabular}{|c|c|}
\hline Pengujian & Nilai \\
\hline Mann Whitney U & 113,000 \\
\hline Wilcoxon W & 303,000 \\
\hline Z & $-2,013$ \\
\hline Asymp. Sig. (2-tailed) & 0,044 \\
\hline
\end{tabular}

Pada tabel 2 pengujian dilakukan menggunakan uji Mann Whitney karena salah satu data tidak berdistribusi normal yaitu data kelas kontrol. Berdasarkan hasil perhitungan Mann Whitney nilai signifikansinya 0,044 . Karena sig < 0,05 maka $\mathrm{H}_{0}$ ditolak. Dengan demikian, dapat disimpulkan bahwa kemampuan awal berpikir kritis matematis siswa kelas eksperimen dan kelas kontrol berbeda.

Karena kedua sampel berangkat dari kemampuan yang berbeda, maka dapat dibandingkan kembali kemampuan berpikir kritis antara kelas eksperimen dan kelas kontrol setelah mendapat perlakuan. Adapun pengujiannya sebagai berikut:

Tabel 3. Uji Kesamaan Rerata Data Posttest

\begin{tabular}{|c|c|c|c|}
\hline Kelas & Rata-rata & s & Sig. \\
\hline Eksperimen & 11,16 & 3,625 & 0,350 \\
\hline Kontrol & 10,00 & 3,902 & 0,350 \\
\hline
\end{tabular}

Berdasarkan tabel 3 terlihat bahwa nilai sig. (2-tailed) uji kesamaan dua rata-rata posttest kelas eksperimen dan kelas kontrol adalah 0,350. Nilai tersebut lebih besar dari 0,05 sehingga dapat dikatakan bahwa rata-rata kemampuan berpikir kritis matematis siswa 
kelas eksperimen dan kelas kontrol sama. Selanjutnya untuk mengetahui peningkatan kemampuan berpikir kritis matematis siswa dilakukan pengujian gain, seperti yang disajikan dalam tabel berikut:

Tabel 4. Uji Kesamaan Dua Rata-rata Data Indeks Gain

\begin{tabular}{|c|c|c|}
\hline Kelas & Sig. (2-tailed) & Sig. (1-tailed) \\
\cline { 1 - 1 } Eksperimen & 0,507 & 0,2535 \\
\hline \multirow{yy}{*}{ Kontrol } & & \\
\hline
\end{tabular}

Pada Tabel 4 diperoleh nilai signifikansi 0,507. Karena pengujian menggunakan uji satu pihak (1-tailed) maka nilai signifikansi (2-tailed) harus dibagi dua sehingga nilai signifikansi (1-tailed) adalah 0,2535. Nilai tersebut $\geq 0,05$ maka $\mathrm{H}_{0}$ diterima.

Berdasarkan analisis kemampuan awal siswa skor pretest kemampuan berpikir kritis matematis kedua kelompok menunjukkan terdapat perbedaan yang signifikan. Artinya secara signifikan kemampuan berpikir kritis siswa kelas eksperimen dan kelas kontrol memiliki kemampuan awal yang berbeda. Kemudian kedua kelompok tersebut diberi perlakuan yang berbeda yaitu, kelompok eksperimen mendapatkan perlakuan berupa model pembelajaran problem solving sedangkan kelas kontrol mendapatkan pembelajaran dengan model discovery learning.

Pada awal pembelajaran, siswa belum terbiasa dengan soal-soal berpikir kritis. Hal ini ditunjukkan pada saat siswa mengerjakan soal pretest. Siswa merasa asing dengan bentuk soal berpikir kritis karena siswa terbiasa dengan soal-soal rutin yang prosedur pengerjaannya melalui penemuan. Pada tahap ini dapat disimpulkan bahwa kemampuan berpikir kritis siswa belum terlatih karena siswa masih mengerjakan soal hanya menerapkan prosedur rutin yang ada.

Tahap kemampuan berpikir kritis tidak hanya dapat menerapkan rumus tetapi dapat menganalisis dan mengevaluasi pengetahuan yang ada yang diterapkan pada masalah non rutin. Hal ini ditegaskan oleh Duron (2006) yang menyatakan bahwa pemikir kritis mampu menganalisis dan mengevaluasi informasi, memunculkan pertanyaan dan masalah yang vital, menyusun pertanyaan dan masalah tersebut dengan jelas, mengumpulkan dan menilai informasi yang relevan menggunakan ide-ide abstrak, berpikiran terbuka, serta mengomunikasikannya dengan efektif.

Kemampuan berpikir kritis siswa masih sangat kurang di awal pembelajaran. Hal ini ditunjukkan dengan pemberian LKS pertemuan pertama yang membahas materi luas permukaan kubus. Dalam menjawab pertanyaan, ada yang bisa menjawab tetapi tidak bisa 
memberikan alasan yang jelas, dan ada pula yang dapat menjawab dan memberi alasan yang tepat, tetapi paling banyak siswa sulit memberi alasan. Siswa masih sulit mengkomunikasikan apa yang ada dipikirannya untuk diuraikan dalam bentuk tulisan. Untuk dapat memberikan jawaban yang disertai alasan, siswa harus memiliki keterampilan mengetahui informasi dengan baik sehingga dapat memberikan alasan yang tepat sesuai informasi yang diperoleh.

Mengatasi permasalahan tersebut model pembelajaran problem solving menjadi salah satu alternatif untuk dapat melatih kemampuan mengolah informasi dengan baik dan memberikan alasan yang tepat atas jawabannya. Model pembelajaran problem solving pada tahap awal menghadapkan siswa pada masalah terbuka. Pada tahap ini secara berkelompok siswa dilatih untuk mengolah informasi dengan baik, kemudian dapat memberikan jawaban dengan alasan yang tepat sesuai kemampuannya.

Tahap selanjutnya pada model pembelajaran problem solving yaitu membimbing siswa untuk memahami dan menyusun rencana penyelesaian masalah. Pada tahap ini siswa diberitahukan konsep dasar sebuah materi dan siswa harus menyusun rencana untuk menyelesaikan masalah yang diberikan. Dengan demikian siswa dilatih untuk mengeluarkan ide-idenya untuk menyelesaikan permasalahan yang ada. Ketika siswa harus menyusun rencana penyelesaian masalah tentunya siswa harus memiliki kemampuan kognitif tinggi. Hal ini sejalan dengan pendapat Choy \& Cheah (2009) yang mendefinisikan berpikir kritis sebagai proses kompleks yang memerlukan kognitif tingkat tinggi dalam memproses informasi.

Tahap selanjutnya pada model pembelajaran problem solving yaitu siswa melaksanakan rencana penyelesaian. Tahap ini dilakukan untuk mencari solusi penyelesaian dari masalah yang diberikan sesuai rencana penyelesaian yang telah dibuat.

Pada tahap ini siswa dilatih untuk mandiri dalam menyelesaikan suatu permasalahannya sendiri sehingga siswa mempunyai kemandirian dalam belajar matematika. Kemandirian belajar siswa muncul karena adanya dorongan dalam diri siswa sendiri untuk belajar menyelesaikan suatu permasalahan. Selain itu siswa terlatih untuk berpikir kritis dalam mencari solusi penyelesaian suatu masalah.

Tahap terakhir model pembelajaran problem solving yaitu memeriksa kembali jawaban yang diperoleh. Pada tahap ini siswa memiliki kemampuan memeriksa kembali jawaban agar dapat menyajikan hasil pembelajaran dengan baik. Kemudian siswa juga harus mempertimbangkan apa yang akan disampaikan terkait jawaban yang akan 
dipresentasikan. Proses ini akan meningkatkan kemampuan berpikir kritis matematis siswa baik siswa yang mempresentasikan maupun siswa yang mendengarkan. Hal ini dipertegas oleh Kalelioğlu \& Gülbahar (2014) yang menyatakan bahwa Berpikir kritis adalah cara berpikir, dan seperangkat keterampilan, yang mendorong pendekatan yang informatif, sadar, sistemik, dipertimbangkan, dan logis untuk memutuskan apa yang harus dipercaya atau dilakukan.

Berdasarkan analisis kemampuan akhir siswa skor posttest kemampuan berpikir kritis matematis kedua kelompok menunjukkan hasil nilai signifikansi (1-tailed) kurang dari taraf signifikansi 0,05, sehingga dapat disimpulkan bahwa peningkatan kemampuan berpikir kritis matematis siswa dengan model pembelajaran problem solving tidak lebih baik / sama dengan siswa yang belajar dengan model discovery learning.

Kesimpulannya, peningkatan kemampuan berpikir kritis matematis siswa menunjukkan bahwa siswa yang pembelajarannya menggunakan model pembelajaran problem solving mempunyai kemampuan berpikir kritis matematis tidak lebih baik / sama dengan siswa yang pembelajarannya menggunakan model discovery learning. Oleh karena itu model pembelajaran problem solving dapat digunakan dalam pembelajaran pada topiktopik tertentu karena model ini dapat memberi ruang untuk siswa berpikir kritis mencari solusi permasalahan sehingga mampu meningkatkan kemampuan berpikir kritis matematis siswa.

\section{Kemandirian Belajar}

Tingkat kemandirian belajar siswa secara umum masih rendah. Hal ini dikarenakan siswa awalnya hanya menuruti apa saja yang disajikan oleh guru atau masih bergantung pada guru. Jika siswa diharapkan menjadi siswa yang mandiri, maka guru harus bisa membuat siswa aktif sendiri dalam menemukan hal-hal baru yang dapat membuat siswa menyelesaikan permasalahan yang diberikan dalam kegiatan pembelajaran.

Pembelajaran berbasis masalah seperti model pembelajaran problem solving dapat meningkatkan kemandirian belajar siswa melalui tahap orientasi siswa pada masalah dan tahap membimbing penyelidikan individual maupun kelompok. Pada tahap orientasi siswa pada masalah, siswa dapat mengembangkan sendiri pengetahuan yang dimilikinya karena siswa dituntut untuk belajar mandiri dengan mencari sendiri solusi dari permasalahan yang diberikan guru. Pada tahap membimbing penyelidikan kelompok, guru mengawasi jalannya diskusi di kelas dan membimbing siswa dalam mengumpulkan informasi dari 
berbagai sumber. Guru hanya memberikan bantuan pada saat siswa benar-benar kesulitan. Jadi, dari tahap-tahap tersebut siswa dapat belajar untuk mencari dan menyelesaikan permasalahan yang diberikan secara mandiri sehingga dapat membentuk kemandirian belajar siswa.

Dari hasil penelitian kemandirian belajar siswa melalui angket dan lembar observasi diperoleh:

\section{Tabel 5. Uji Mann Whitney Indeks Gain Data Angket Kemandirian Belajar}

\begin{tabular}{|c|c|c|}
\hline Kelas & Asymp. Sig-(2-tailed) & Asymp. Sig-(1-tailed) \\
\cline { 1 - 2 } Eksperimen & 0,002 & 0,001 \\
\hline Kontrol & & \\
\hline
\end{tabular}

Dilihat dari tabel 5 diperoleh nilai signifikansi 0,002. Karena pengujian menggunakan uji satu pihak (1-tailed) maka nilai signifikansi (2-tailed) harus dibagi dua sehingga nilai signifikansi ( 1 -tailed) adalah 0,001. Nilai tersebut $<0,05$ maka $\mathrm{H}_{0}$ ditolak. Dengan demikian dapat disimpulkan bahwa peningkatan kemandirian belajar siswa kelas eksperimen lebih baik daripada kelas kontrol. 
Tabel 6. Hasil Analisis Lembar Observasi Kemandirian Belajar Kelas Eksperimen

\begin{tabular}{|c|c|c|c|c|c|c|c|c|}
\hline \multirow{3}{*}{ No } & \multirow{3}{*}{$\begin{array}{c}\text { Indikator } \\
\text { Kemandirian }\end{array}$} & \multicolumn{6}{|c|}{ Pertemuan ke- } & \multirow{3}{*}{ Rata-rata } \\
\hline & & \multicolumn{2}{|c|}{ I } & \multicolumn{2}{|c|}{ II } & \multicolumn{2}{|c|}{ III } & \\
\hline & & $\begin{array}{c}\text { Jml } \\
\text { Siswa }\end{array}$ & & $\begin{array}{c}\text { Jml } \\
\text { Siswa }\end{array}$ & & $\begin{array}{c}\text { Jml } \\
\text { Siswa }\end{array}$ & & \\
\hline 1 & $\begin{array}{l}\text { Tidak tergantung } \\
\text { terhadap orang lain }\end{array}$ & 13 & $68 \%$ & 16 & $84 \%$ & 18 & $95 \%$ & $82,3 \%$ \\
\hline 2 & $\begin{array}{c}\text { Memiliki } \\
\text { kepercayaan diri }\end{array}$ & 14 & $74 \%$ & 17 & $89 \%$ & 16 & $84 \%$ & $82,3 \%$ \\
\hline 3 & $\begin{array}{c}\text { Berperilaku } \\
\text { disiplin }\end{array}$ & 19 & $\begin{array}{c}100 \\
\%\end{array}$ & 19 & $\begin{array}{c}100 \\
\%\end{array}$ & 18 & $95 \%$ & $98,3 \%$ \\
\hline 4 & $\begin{array}{c}\text { Memiliki rasa } \\
\text { tanggung jawab }\end{array}$ & 10 & $53 \%$ & 15 & $79 \%$ & 10 & $53 \%$ & $61,7 \%$ \\
\hline 5 & $\begin{array}{c}\text { Berperilaku } \\
\text { berdasarkan } \\
\text { inisiatif sendiri }\end{array}$ & 6 & $32 \%$ & 5 & $26 \%$ & 5 & $26 \%$ & $28 \%$ \\
\hline 6 & $\begin{array}{c}\text { Melakukan kontrol } \\
\text { diri }\end{array}$ & - & $0 \%$ & 4 & $21 \%$ & 8 & $42 \%$ & $21 \%$ \\
\hline & & $s$ & & & & & & $62,3 \%$ \\
\hline
\end{tabular}

Dari tabel 6 dan tabel 7 terlihat persentase rata-rata kelas eksperimen adalah 62,3\% dan persentase rata-rata kelas kontrol adalah 44,7\%. Dari persentase tersebut maka dapat dikatakan bahwa kelas eksperimen sebagian besar siswanya memiliki kemandirian belajar. Sedangkan dari persentase kelas kontrol dapat dikatakan bahwa hampir setengah siswanya memiliki kemandirian belajar. Sehingga dapat disimpulkan bahwa kemandirian belajar kelas eksperimen lebih baik daripada kelas kontrol. 
Tabel 7. Hasil Analisis Lembar Observasi Kemandirian Belajar Kelas Kontrol

\begin{tabular}{|c|c|c|c|c|c|c|c|c|}
\hline \multirow{3}{*}{ No } & \multirow{3}{*}{$\begin{array}{c}\text { Indikator } \\
\text { Kemandirian }\end{array}$} & \multicolumn{6}{|c|}{ Pertemuan ke- } & \multirow{3}{*}{$\begin{array}{l}\text { Rata- } \\
\text { rata }\end{array}$} \\
\hline & & \multicolumn{2}{|c|}{ I } & \multicolumn{2}{|c|}{ II } & \multicolumn{2}{|c|}{ III } & \\
\hline & & $\begin{array}{c}\text { Jml } \\
\text { Siswa }\end{array}$ & & $\begin{array}{c}\text { Jml } \\
\text { Siswa }\end{array}$ & & $\begin{array}{c}\text { Jml } \\
\text { Siswa }\end{array}$ & & \\
\hline 1 & $\begin{array}{l}\text { Tidak tergantung } \\
\text { terhadap orang lain }\end{array}$ & 13 & $68 \%$ & 14 & $74 \%$ & 13 & $68 \%$ & $70 \%$ \\
\hline 2 & $\begin{array}{c}\text { Memiliki } \\
\text { kepercayaan diri }\end{array}$ & 7 & $37 \%$ & 8 & $42 \%$ & 10 & $53 \%$ & $44 \%$ \\
\hline 3 & Berperilaku disiplin & 17 & $89 \%$ & 16 & $84 \%$ & 13 & $68 \%$ & $80,3 \%$ \\
\hline 4 & $\begin{array}{l}\text { Memiliki rasa } \\
\text { tanggung jawab }\end{array}$ & 6 & $32 \%$ & 7 & $37 \%$ & 13 & $68 \%$ & $45,7 \%$ \\
\hline 5 & $\begin{array}{c}\text { Berperilaku } \\
\text { berdasarkan inisiatif } \\
\text { sendiri }\end{array}$ & 3 & $16 \%$ & 4 & $21 \%$ & 5 & $26 \%$ & $21 \%$ \\
\hline 6 & $\begin{array}{c}\text { Melakukan kontrol } \\
\text { diri }\end{array}$ & 1 & $5 \%$ & 0 & $0 \%$ & 3 & $16 \%$ & $7 \%$ \\
\hline & & ersent & Rata & rata & & & & $44,7 \%$ \\
\hline
\end{tabular}

\section{Simpulan}

Berdasarkan hasil penelitian dan pembahasan, diperoleh kesimpulan serta jawaban dari rumusan masalah bahwa peningkatan kemampuan berpikir kritis matematis siswa yang menggunakan model pembelajaran Problem Solving tidak lebih baik daripada peningkatan kemampuan berpikir kritis matematis siswa yang menggunakan model Discovery Learning, dan kemandirian belajar siswa yang menggunakan model pembelajaran Problem Solving lebih baik daripada kemandirian belajar siswa yang menggunakan model Discovery Learning. 


\section{Referensi}

Arora, W., dkk. (2013). Hubungan Antara Perlakuan Orang Tua dengan Kemandirian Siswa dalam Belajar. Jurnal Ilmiah Konseling, 2 (1), 304-309. http://ejournal.unp.ac.id/ index.php/konselor

Choy, S. C., \& Cheah, P. K. (2009). Teacher Perception of Critical Thinking Among Students and Its Influence on Higher Education. International Journal of Teaching and Learning in Higher Education, 20(2), 198-206. Retrieved from http://www.isetl.org/ijtlhe/ pdf/IJTLHE336.pdf.

Dewi, P. S., \& Septa, H. W. (2019). Peningkatan Kemampuan Pemecahan Masalah dan Disposisi Matematis Siswa dengan Pembelajaran Berbasis Masalah. Mathema Journal, 1 (1), 31-39.

Duron, R., dkk. (2006). Critical Thinking Framework for Any Discipline. International Journal of Teaching and Learning in Higher Education, 17(2), 160-166. Retrieved from http://www.isetl.org/ijtlhe/pdf/IJTLHE55.pdf.

Elfira, N. (2013). Peningkatan Kemandirian Belajar Siswa Melalui Layanan Bimbingan Kelompok. Jurnal Ilmiah Konseling, 2 (1), 279-282. http://ejournal.unp.ac.id/ index.php/konselor

Ennis, R. H. 1962. A concept of critical thinking. Harvard Educational Review, Vol 32(1), 81-111.

Firmansyah,. dkk. (2016). Penerapan Model Pembelajaran Problem Solving Berbantuan WEB Pada Materi Ekstraksi Terhadap Hasil Belajar dan Motivasi Mahasiswa. Jurnal Penelitian Sains, 4(2), 65-72. Tersedia online di http://journal.um.ac.id/index.php/jps/.

Handayani, N., \& Hidayat, F. (2018). Hubungan Kemandirian Terhadap Hasil Belajar Siswa Mata Pelajaran Matematika di Kelas X SMK Kota Cimahi. Journal On Education, 01(02), 1-8.

Herdiman, I., dkk. (2018). Kemampuan Berpikir Kritis Matematik Siswa SMP Pada Materi Lingkaran. Jurnal Prisma, VII(1). https://jurnal.unsur.ac.id/prisma.

Herlina, M. \& Ihsan I.R. (2020). Penelitian Pendahuluan Mengenai LKPD Model PBL Terkait Kemampuan Berpikir Matematis. Mathema Journal, 2 (2), 46-54.

Hidayat, D. \& Ihsan I.R. (2020). Desain Pembelajaran Model Problem Based Learning Terkait Kemampuan Berpikir Kreatif Matematis dan Adversity Quotient Peserta Didik. Mathema Journal, 2 (2).

Huda, M., dkk. (2019). Kemandirian Belajar Berbantuan Mobile Learning. PRISMA, Prosiding Seminar Nasional Matematika 2, 798-806.

Kalelioğlu, F., \& Gülbahar, Y. (2014). The Effect of Instructional Techniques on Critical Thinking and Critical Thinking Dispositions in Online Discussion. Educational Technology \& Society, 17 (1), 248-258.

Nugrahaeni, A., dkk. (2017). Penerapan Model Pembelajaran Discovery Learning untuk Meningkatkan Kemampuan Berpikir Kritis dan Hasil Belajar Kimia. Jurnal Pendidikan Kimia Indonesia, 1 (1).

Nurrohmi, Y., dkk. (2017). Pengaruh Model Pembelajaran Discovery Learning Terhadap Kemampuan Berpikir Kritis Mahasiswa. Jurnal Pendidikan: Teori, Penelitian, dan Pengembangan, 10 (2), 1308-1314. http://journal.um.ac.id/index.php/jptpp/

Puspaningtyas, N. (2019). Berpikir Lateral Siswa SD dalam Pembelajaran Matematika. Mathema Journal, 1 (1), 24-30.

Saefullah,A., dkk. (2013). Hubungan Antara Sikap Kemandirian Belajar dan Prestasi Belajar Siswa Kelas X Pada Pembelajaran Fisika Berbasisi Portofolio. Jurnal Wahana Pendidikan Fisika, 1, 26-36. 
Shoimin, A. (2014). 68 Model Pembelajaran Inovatif dalam Kurikulum 2013. Yogyakarta:Ar-Ruzz Media.

Suid., dkk. (2017). Analisis Kemandirian Siswa dalam Proses Pembelajaran di Kelas III SD Negeri 1 Banda Aceh. Jurnal Pesona Dasar, 1 (5), 70-81.

Widayanti, R. \& Nur'aini K. D. (2020). Penerapan Model Pembelajaran Problem Based Learning untuk Meningkatkan Prestasi Belajar Matematika dan Aktivitas Siswa. Mathema Journal, 2 (1), 12-23. 